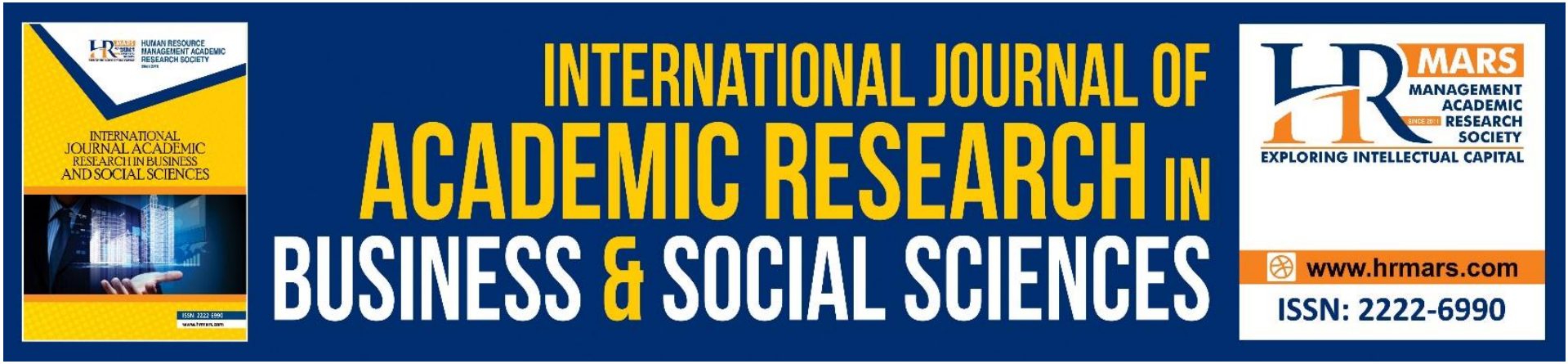

\title{
A Review on Impact of Entrepreneurship Training Program towards Entrepreneur's Entrepreneurial Performance
}

Nuraisya Maisara Md Noor Aizuddin, Sabrinah Adam

To Link this Article: http://dx.doi.org/10.6007/IJARBSS/v11-i4/9732

DOI:10.6007/IJARBSS/v11-i4/9732

Received: 06 February 2021, Revised: 13 March 2021, Accepted: 31 March 2021

Published Online: 25 April 2021

In-Text Citation: (Aizuddin \& Adam, 2021)

To Cite this Article: Aizuddin, N. M. M. N., \& Adam, S. (2021). A Review on Impact of Entrepreneurship Training Program towards Entrepreneur's Entrepreneurial Performance. International Journal of Academic Research in Business and Social Sciences, 11(4), 771-779.

\section{Copyright: @ 2021 The Author(s)}

Published by Human Resource Management Academic Research Society (www.hrmars.com)

This article is published under the Creative Commons Attribution (CC BY 4.0) license. Anyone may reproduce, distribute, translate and create derivative works of this article (for both commercial and non-commercial purposes), subject to full attribution to the original publication and authors. The full terms of this license may be seen at: http://creativecommons.org/licences/by/4.0/legalcode

Vol. 11, No. 4, 2021, Pg. 771 - 779

Full Terms \& Conditions of access and use can be found at http://hrmars.com/index.php/pages/detail/publication-ethics 


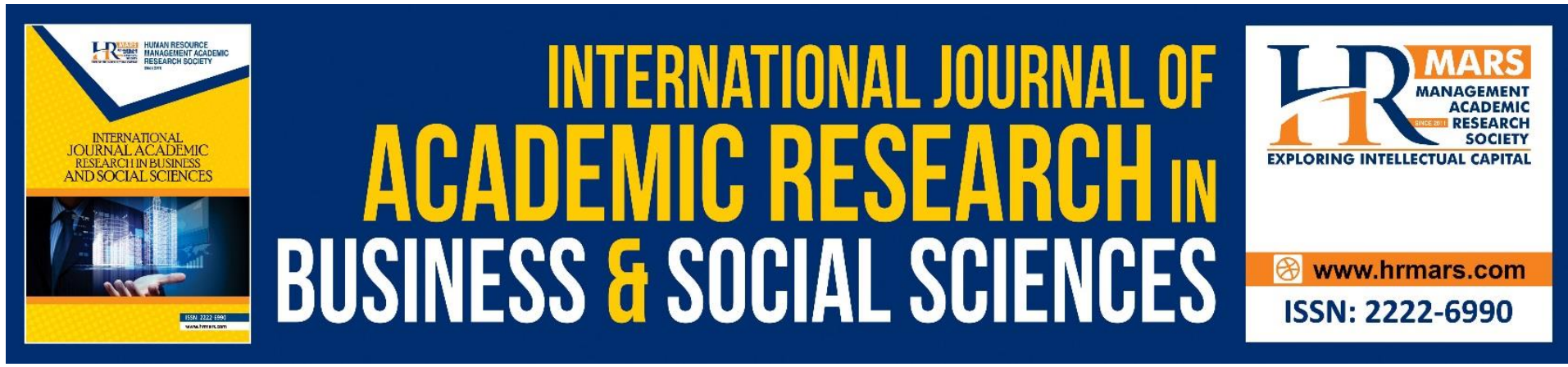

\title{
A Review on Impact of Entrepreneurship Training Program towards Entrepreneur's Entrepreneurial Performance
}

\author{
Nuraisya Maisara Md Noor Aizuddin, Sabrinah Adam \\ Azman Hashim International Business School, Universiti Teknologi Malaysia (UTM), \\ Malaysia. \\ Email: nuraisyamaisara@graduate.utm.my
}

\begin{abstract}
The purpose of the study is to examine the impact of entrepreneurship training program towards the entrepreneur's entrepreneurial performance. The study applied mixed method research that consists of qualitative and quantitative method. Data is collected from a total of 217 entrepreneurs as the respondent of the study. Miles and Huberman technique and SPSS version 25 were used in the study for data analysis. Intervention was designed to improve the entrepreneurship training conducted. The outcome of the study found that entrepreneurship training program give significant impact on entrepreneurs by increasing their entrepreneurial skills, business skills and performance.
\end{abstract}

Keywords: Entrepreneurship Training Program, Entrepreneurial Performance.

\section{Introduction}

Entrepreneurs that able to equip themselves with entrepreneurship knowledge will be able to enhance their entrepreneurial performance (EP) (Audretsch \& Keilbach, 2007).. Financial and non-financial are the two factors that can be used to determine the level of EP of the entrepreneurs. Several measures that can impact non-financial factor such as motivation, managerial skills and knowledge (Al Mamun, Fazal, \& Muniady, 2019).. EP is important in entrepreneurship as it can bring success to enterprises and contribute to the economic growth of a country.

The entrepreneurship field has to get more attention and this leads to various entrepreneurship training programs being held to guide entrepreneurs to become a success. Various government and private agencies provide training for entrepreneurs in different sectors. The purpose of the entrepreneurship training program is to equip entrepreneurs with crucial skills and provide guidance in order to for them to give positive output in terms of their enterprise's profitability (Coelho, Marques, Loureiro, \& Ratten, 2018).. Commonly, most of entrepreneurship training programs contribute to a positive impact on entrepreneurs such as an increase in skills, knowledge and enterprise performance (Warhuus et al., 2017). 
However, there is a lack of evidence of whether these entrepreneurship training programs being conducted really give an impact on the entrepreneurs. Most of entrepreneurship training program is conducted without any reflection on the effectiveness of the program (Nasr \& Boujelbene, 2014).. There is not enough evidence of whether these training programs are effective in enhancing entrepreneur's entrepreneurial performance. Assessing and evaluating the program is crucial in determining whether the training program able to delivers good value to entrepreneurs (Galvao, 2019).

\section{Literature Review \\ Entrepreneurship Training}

Entrepreneurship training is important to be evaluated in order to enhance entrepreneurial skills. A good entrepreneurship training program will able to improve an entrepreneur's skills, knowledge and competency. Entrepreneurship influence people to create innovative businesses and increase their standard of living (Ismail, 2018).

Apart from that, entrepreneurship training programs act as a practical means that help to equip entrepreneurs with relevant skills (Ho, Uy, Kang, \& Chan, 2018).Formal training such as structured training is focusing on entrepreneurial skills that entrepreneurs need to acquire such as technical skills, marketing skills, business skills and financial skills. Informal training mainly focusing on coaching, mentoring and counseling (de Faoite, Henry, Johnston, \& Van Der Sijde, 2003).. Besides, entrepreneurship training programs help entrepreneurs to develop good business practices (Ismail, 2018).

Entrepreneurship programs are varied in terms of content and objective thus there is a need in the assessment of entrepreneurs. The assessment of entrepreneurs is crucial as it ensures that the training programs conducted are giving a positive impact on the entrepreneurs. Besides, the assessment also can improve the training programs in terms of method, content and objective in the future (Warhuus et al., 2017)

A study conducted by (Yaqoot, Noor, \& Isa, 2017)on the effectiveness of entrepreneurship training among entrepreneurs in Bahrain. The findings collected by the researchers were that effective entrepreneurship training influenced entrepreneur's behavior, learning, reaction and result. This is aligned with findings obtained by Ismail (2018) that stated the entrepreneurship training give an impact on business knowledge and practices. Thus, entrepreneurship training is important in influencing entrepreneurs to improve their abilities and able to seek business opportunities (Coelho et al., 2018)..

\section{Entrepreneurial Performance}

Entrepreneurial performance (EP) can be referred to as the action of an entrepreneur that influences their businesses. The action involves what entrepreneurs do to achieve desired business achievement. The EP of an entrepreneur is mostly influenced by their skill, individual traits and social factors. Moreover, the entrepreneurial performance shows the utilization of opportunities to enhance business ideas. Entrepreneurial knowledge and skills are the major factors of entrepreneurial performance (Sebikari, 2019).

EP also can be referred to as the growth or decline of a business entity (Tambwe, 2015). The growth or decline of a business entity points out the success or failure face by the 
entrepreneurs in operating their business. A study on the impact of entrepreneurship training on entrepreneurial performance in Tanzania found that entrepreneurship training give an impact on entrepreneurs by enhancing their entrepreneurial performance (Tambwe, 2015). The researcher also stated that entrepreneurship training provides entrepreneurs with a competitive advantage. (Hassan, Ramli, \& Mat Desa, 2014) conducted a study in Malaysia's SMEs on the factors that influence entrepreneurial performance success. Several factors were justified that influence entrepreneurial performances are risk-taking behavior and entrepreneurs' confidence.

\section{Research Methodology}

The mixed-method approach is used in the study. The mixed-method comprises of collecting data by using both qualitative and quantitative (Saunders et al, 2009).. A sample of 217 respondents from a total of 500 population of entrepreneurs will be used in the study. Purposive sampling technique was applied for the qualitative method and stratified sampling was used for the quantitative method.

The data collection used in the study is primary data. Two types of research instruments will be used in the study which are interview and questionnaire. The interview will be conducted with the participants through a proper interview protocol. The interview will be conducted by one-to-one interviewing.

Table 1: The Interview Protocol

\section{Interview Protocol}

1. Set an appointment with the interviewee.

2. Ask permission to record the interview and brief the interviewee regarding the purpose of the interview.

3. Start with the introduction and background of the interviewee.

4. Start the interview with the validated interview questions prepared.

5. Prepare an interview transcript.

6. Start coding the transcript to discover themes.

For quantitative method, a set of questionnaires will be distributed to the 217 respondents. The questionnaire consists of 4 sections. Section A covers the demographic analysis, while section B comprises of the entrepreneurial performance. Section $C$ consists of the business skill and the last section, which is section $D$ covers the entrepreneurial skill. The questionnaires constructed are based on the objectives of the study. The quantitative data collected from the questionnaires is capable in collecting a lot of information and it is easy to analyze and make comparisons (Yaqoot et al., 2017). 
Table 2: Data collection method.

No. Research Questions

Approaches

Data Analysis

What are the factors that can
impact entrepreneurial
1. performance among

Bumiputera entrepreneurs?

Qualitative

Method- Interview

Miles and
Huberman
Technique (2014)

How an improvement in the entrepreneurship training

2. programs can influence the level of Bumiputera entrepreneurial performances?

\section{Quantitative}

Method- SPSS version 25

Questionnaires

\section{A Proposed Conceptual Model \\ Conceptual Model of Entrepreneurship}

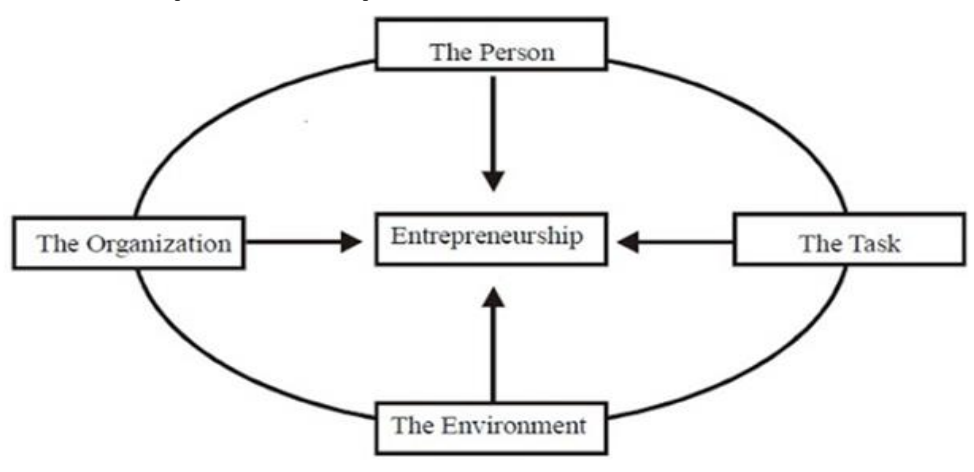

(Source: John Kao, 1989)

Figure 1: The Conceptual Model of Entrepreneurship.

Figure 1 above shows the conceptual model of entrepreneurship. The factors consist of the person, task, organization and environment. From a personal perspective, the individual is an important key in entrepreneurship. The success of entrepreneurs depends on the trait characteristics of the entrepreneur itself. Individuals need to be able to acquire certain skills, experience and motivation to develop entrepreneurship. Secondly, is the task. An entrepreneur must be able to perform several tasks such as opportunity recognition and finding resources. Next is the environment. The environment will influence, hinders or can facilitate the growth of entrepreneurship. Several environmental factors can influence entrepreneurship such as economic, legal and political. Lastly, is the organization. Entrepreneurs need to build their organization with creativity and innovation. The development of an organization includes the culture, rule, structure and policies. An organization needs to specify a specific vision and task to be performed. In this study, the researcher will focus more on the person based on the model. 


\section{Entrepreneurial Performance Training model}

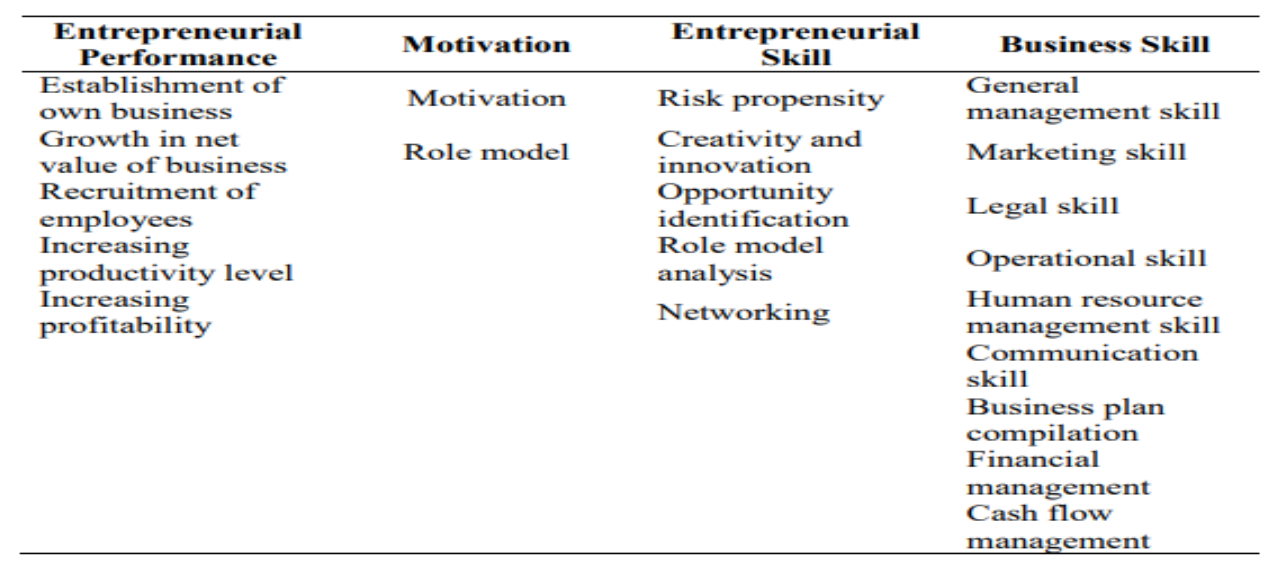

Figure 2: The Entrepreneurial Performance Training Model.

The entrepreneurial performance training model is adapted from Antonites, (2002). The model emphasizes on several factors that can influence entrepreneurial performance for entrepreneurs. The factors are performance motivation, entrepreneurial skill and business skill. These 4 factors are the elements that able to enhance entrepreneurial performance.

Utilizing the opportunity, increasing productivity, profitability and innovative business ideas shows that an entrepreneur has a good entrepreneurial performance. There is a relationship between personality and work environment as it can affect performance (van Vuuren \& Botha, 2010).As there is a strong relationship between personality and work environment, thus it can lead to greater entrepreneurial performance. The entrepreneurial performance of an entrepreneur may enhance as a result of achieving the entrepreneurial goals. It means that entrepreneurs need to achieve entrepreneurial goals such as productivity, profitability to increase entrepreneurial performance. Entrepreneurs who able to accomplish the need for achievement may lead to a successful performance (Davis \& McClelland, 1962).. The entrepreneurial skills in the model focus on several skills which are risk propensity, creativity, innovation, opportunity identification and networking. Individuals that able to perform these entrepreneurial skills are likely to achieve success in their business. For the business skills, (van Vuuren \& Botha, 2010) emphasize that the management skill is important for entrepreneurs to run their business smoothly.

\section{Result}

Objective 1: To identify the factors that impact entrepreneurial performance among Bumiputera entrepreneurs.

For the first research question, qualitative analysis was implemented. An interview with the participant was conducted to determine the effectiveness in the second cycle and identify other factors that may impact entrepreneurial performance. The table below shows the demographic profile of the participated participant. 
Table 3: The participant's profile.

\begin{tabular}{ccccc}
\hline Participant & Age & Gender & $\begin{array}{c}\text { Education } \\
\text { level }\end{array}$ & $\begin{array}{c}\text { Business } \\
\text { cluster }\end{array}$ \\
\hline C & 25 & Female & STPM & $\begin{array}{c}\text { Food \& } \\
\text { beverage }\end{array}$ \\
\hline
\end{tabular}

The interview was conducted following the interview protocol. 3 questions were asked to the participant to answer. The participant was asked to briefly introduce their business background. Then, the participant was asked how entrepreneurship training is addressing their need. The participant mentioned that;

"The programs are great as we have to brainstorm to solve problems and this can help us adapt in our enterprises."

(Participant C)

The participant mentioned that the experiential learning implemented by the program enables them to brainstorm solutions to solve problems. This means that meaningful learning has taken place in the training program.

Next, the participant was asked on what are other important skills that entrepreneurs need to acquire to operate the business. The participant stated that;

"I think entrepreneurs need to acquire many skills. I need to have a good communication with my customer to avoid any issue on their expectation of my products later."

(Participant C)

Based on the answer given by participant $C$, it was mentioned that communication skill is important for the entrepreneurs. Based on the interview conducted, it can be highlighted that the entrepreneurship training program give a positive impact on the participant.

Khalili, Tojari \& Rezaei (2014) stated that entrepreneurship training programs give a positive impact on risk-taking skills among entrepreneurs. Entrepreneurship training is effective when it increases the entrepreneurs' capabilities and skills. Based on research by (Ho et al., 2018), they stated that entrepreneurship training programs are effective in enhancing entrepreneurial skills. This is because the learning strategy that is adopted in the program lets entrepreneurs develop various entrepreneurial skills. The training program helps them to practice and evaluating real problems that may occur future in business.

Objective 2: To determine the impact of improvement on the level of entrepreneurial performance among Bumiputera entrepreneurs.

A quantitative approach was applied to assess the second objective. The same questionnaire was adapted to evaluate the effectiveness of the second cycle towards the entrepreneurial performance among the participated entrepreneurs. Wilcoxon test was conducted for each variable from the study to evaluate the effectiveness of the intervention.

Table 4: Descriptive statistics.

\begin{tabular}{|l|c|c|c|}
\hline \multicolumn{4}{|c|}{ Descriptive statistic } \\
\hline Before & $\mathrm{N}$ & Mean & Standard Deviation \\
\hline After & 217 & 4.3658 & 0.2328 \\
\hline
\end{tabular}

Table 4 above shows the descriptive statistic for overall analysis where the mean for before intervention is 4.3658 and the mean for after intervention is 4.4259 . 
Table 5: Summary of analysis after the intervention.

\begin{tabular}{|c|c|c|}
\hline Condition & Findings & Result \\
\hline P-value $<0.05$ & $0.000<0.05$ & Significant \\
\hline $\begin{array}{c}\text { Calculation value }<\text { Critical } \\
\text { value }\end{array}$ & $55.5<434^{*}$ & Significant \\
\hline \multicolumn{2}{|c|}{ The null hypothesis is rejected. Thus, there is a difference between before and after. } \\
\hline
\end{tabular}

*The critical value for the Signed rank test only up to $N=50$. Thus, for $N>50$, the critical value should be more than 434 .

The P-value obtained from the test is lower than the critical value $(0.000<0.05)$ and this indicates that the result is significant. The calculation value obtained from the analysis is lower than the critical value from the Signed Rank test table. Thus, based on the result, the null hypothesis is rejected and to conclude, there is a difference between before and after the intervention.

The finding from the study shows that the entrepreneurship training program intervention give an impact on the business skill, entrepreneurial skill and entrepreneurial performance of the participated entrepreneurs. This can be supported by finding from (Al Mamun et al., 2019)where they found that entrepreneurial skill has a significant impact on entrepreneurial performance. Entrepreneurial skill is one of the entrepreneurial competencies that can enhance the entrepreneurial performance of the entrepreneurs. Entrepreneurs needed to acquire entrepreneurial skills to improve the way they manage their enterprises.

\section{Conclusion}

It was observed that the entrepreneurship training program does give an impact on the entrepreneurial performance of the entrepreneurs. Each factor, business skill and entrepreneurial skill that was obtained from the study give a significant impact on entrepreneurial performance. Based on the study, it is important for entrepreneurship training to have a good intervention in order to really give a positive impact on entrepreneurs.

It is recommended for the study to be extended in the future in order to explore more on entrepreneurship training programs. For the future researcher to conduct research in entrepreneurship they need to consider implementing intervention for a longer period of time. The actual duration for intervention is within 18 months in order to get a better result and enhance the effectiveness of the intervention (van Vuuren \& Botha, 2010).

This study gives insight for an entrepreneurship training provider to improve the entrepreneurship training program provide for entrepreneurs. The study can be used as a reference to address other issues regarding entrepreneurship training programs. Therefore, the approach in the entrepreneurship training program need to be revised in order to give a positive impact and enhance entrepreneur's entrepreneurial performance. Entrepreneur's development organization and government agency need to make sure that the entrepreneurship training program provided can enable these entrepreneurs to improve their enterprises performance.

Thus, the study may give contribution to the industry as it can provide a clear view on the effectiveness of the entrepreneurship training program conducted. Besides, practitioners are able to see whether the entrepreneurs are actually able to perform entrepreneurial skills even after they have participated in the training program. An improvised approaches and method 
need to be established in order to enhance the entrepreneur's entrepreneurial performance through the training program.

\section{References}

Al Mamun, A., Fazal, S. A., \& Muniady, R. (2019). Entrepreneurial knowledge, skills, competencies and performance. Asia Pacific Journal of Innovation and Entrepreneurship. https://doi.org/10.1108/apjie-11-2018-0067

Audretsch, D. B., \& Keilbach, M. (2007). The theory of knowledge spillover entrepreneurship. Journal of Management Studies. https://doi.org/10.1111/j.1467-6486.2007.00722.x

Coelho, F. J. M., Marques, C., Loureiro, A., \& Ratten, V. (2018). Evaluation of the impact of an entrepreneurship training program in Recife, Brazil. Journal of Entrepreneurship in Emerging Economies. https://doi.org/10.1108/JEEE-10-2017-0077

Davis, R. C., \& McClelland, D. C. (1962). The Achieving Society. Technology and Culture. https://doi.org/10.2307/3100843

De Faoite, D., Henry, C., Johnston, K., \& Van Der Sijde, P. (2003). Education and training for entrepreneurs: A consideration of initiatives in Ireland and The Netherlands. Education + Training. https://doi.org/10.1108/00400910310508829

Hassan, F., Ramli, A., \& Mat Desa, N. (2014). Rural Women Entrepreneurs in Malaysia: What Drives Their Success? International Journal of Business and Management. https://doi.org/10.5539/ijbm.v9n4p10

Ho, M. H. R., Uy, M. A., Kang, B. N. Y., \& Chan, K. Y. (2018). Impact of Entrepreneurship Training on Entrepreneurial Efficacy and Alertness among Adolescent Youth. Frontiers in Education. https://doi.org/10.3389/feduc.2018.00013

Nasr, K. Ben, \& Boujelbene, Y. (2014). Assessing the Impact of Entrepreneurship Education. Procedia - Social and Behavioral Sciences. https://doi.org/10.1016/j.sbspro.2013.12.534

Saunders et al. (2009). Research Methods for Business Students, 5th ed. Harlow: Prentice-Hall. International Journal of the History of Sport.

Sebikari, K. V. (2019). Entrepreneurial performance and small business enterprises in Uganda. International Journal of Social Sciences Management and Entrepreneurship.

Van Vuuren, J., \& Botha, M. (2010). The practical application of an entrepreneurial performance training model in South Africa. Journal of Small Business and Enterprise Development. https://doi.org/10.1108/14626001011088750

Warhuus, J. P., Tanggaard, L., Robinson, S., \& Ernø, S. M. (2017). From I to We: collaboration in entrepreneurship education and learning? Education and Training. https://doi.org/10.1108/ET-08-2015-0077

Yaqoot, E. S. I., Noor, W. S. W. M., \& Isa, M. F. M. (2017). Factors Influencing Training Effectiveness : Evidence from Public Sector in Bahrain. Economica. 